\title{
1,1-ジクロルエタンの選択的塩素置換に 関する研究
}

$$
\text { 村 岡 竜 二*・羽 仁 浩* }
$$

Chlorination of 1,1-Dichloroethane.

Ryuji Muraoka* and Hiroshi Hani*

An ordinary photochlorination of 1,1-dichloroethane gave 1,1,1-trichloroethane and 1,1,2-trichloroethane in a yield of $75 \%$ and $22 \%$, respectively.

In the present study, it was found that the selectivity for 1,1,1-trichloroethane was markedly improved when carbon disulfide was bresent. Such effects of carbon disulfide varied depending on its concentration and the reaction temperatures. When 1,1-dichloroethane was photochlorinated in the presence of $8 \mathrm{~mol} / 1$ carbon disulfide, 1,1,1-trichloroethane was obtained with a selectivity of $85 \sim 90 \%$ over a temperature range from $18^{\circ} \mathrm{C}$ to $45^{\circ} \mathrm{C}$. The rate of the reaction decreased in the presence of carbon disulfide.

\section{I. 緒言}

1,1-ジクロルエタンを光化学的に塩素化する際に，1, 1,1-トリクロルエタンを選択的に生成させ， 1, 1,2-トリ クロルエタンの生成率を減少させる方法について検討を 加えた。

A.J. Haefner ${ }^{1)}$ は溶媒に二硫化炭素を用いると 1,1 ， 1ートリクロルエタンの生成率が増加することを述べてい るが詳細は不明である。

そこで炭化水素の光化学的塩素置換反応に際し, 塩素 原子とコンプレックスを作り，塩素の置換位置に対して 特異な選択性を与えるといわれる各種溶媒 ${ }^{2,3)}$ の効果を 本反応について検討すると共に，二硫化炭素を用いたと きの選択的塩素化について若干の新しい知見を得た。

\section{II. 実験方法}

* 旭硝子株式会社研究所（横浜市神奈川区羽沢町松原 1150)

* Research Laboratory, Asahi Glass Co., Ltd., (1150, Matsubara, Hazawa-cho, Kanagawa-ku, Yokohama, Japan)
反応は常圧で回分法によった。

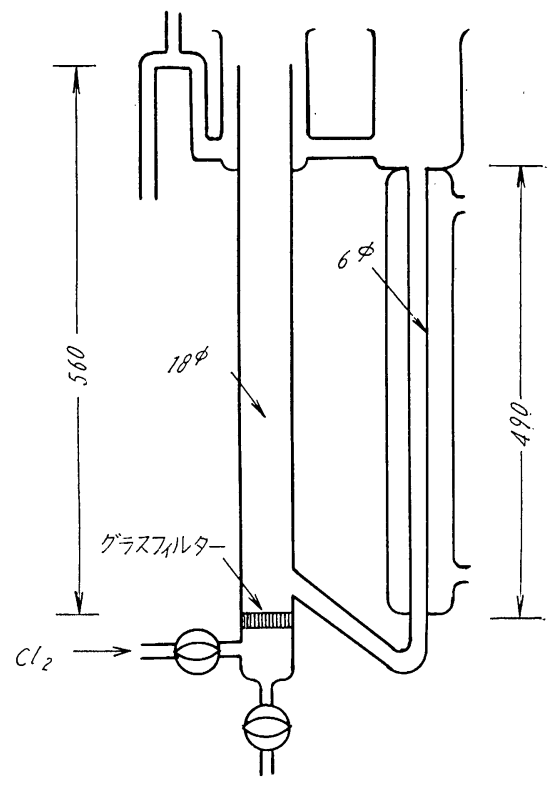

図 1 反応管 
塩素はボンベより食塩を飽和させた貯槽に貯わえ, 濃 硫酸により乾燥させてから流速を一定 $(30 \mathrm{ml} / \mathrm{min})$ に 保つため流量計を通し, 細孔から反応管に泡出させた。 反応管に（図 1) ケイ光灯あるいは水銀灯（東芝理化学 用 $400 \mathrm{~W}$ ) の光を照射し，グラファイトポンプで温 水 または氷冷水を側管のジャケットに循環させ反応温度を

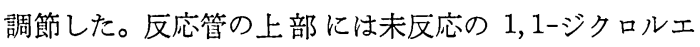
タンおよび低沸点の溶媒を凝縮還流させるためコンデン サーを備えた。反応管から出た未反応塩素と発生した塩 化水素は水酸化ナトリウム溶液㐰吸収させた。また反応 液より分析用試料を採取するときは，塩素の吹き込みを 停止し, 窒素ガスを吹き込み塩化水素と塩素を追、出し てからヨウ素滴定で吸収ビン中の塩素量を求め, ガスク ロマトグラフィーによる生成物の分析から反応した塩素 量を計算し，それぞれの合計を塩素吹き込み量とした。

溶媒に二硫化炭素を用いた場合には，微量の四塩化炭 素と塩化イオウを生ずるので水洗してから炭酸水素ナト リウムを用いて塩化水素および末反応塩素を除き無水塩 化カルシウムで乾燥後, ガスクロマトグラフに注入し た。(装置: GCG 220 型, カラム : 流動パラフィン $5 \mathrm{~m}$, キャリアーガス: 水素, 流速 : $40 \mathrm{ml} / \mathrm{min}$, 温度 : $127^{\circ} \mathrm{C}$, 検出器: 熱伝導度型)

また生成物の同定は標準物質との保持時間の比較によ ったが，この分析法でほぼ満足な塩素収支がえられた。

実験結果に用いた転化率および選択率は次式から算出 てた。

転化率＝(反応した塩素および 1,1-ジクロルエタン) /
（吹き込み塩素量および仕込み 1,1-ジクロルエタン） $(\mathrm{mol} / \mathrm{mol}) \times 100$

選択率＝(生成した塩化物)/(反応した1,1-ジクロルエ タン) $(\mathrm{mol} / \mathrm{mol}) \times 100$

\section{III. 実験結果および考察}

1. 溶媒およひ添加剤の効果 1,1-ジクロルエタン に水銀灯の光を照射して直接塩素化すると約 $60 \%$ の選 択率で 1,1,1-トリクロルエタンが得られた。さらに比 較的照度の弱いケイ光灯を用いて塩素化を同様に行ない

図 2 の結果を得た。

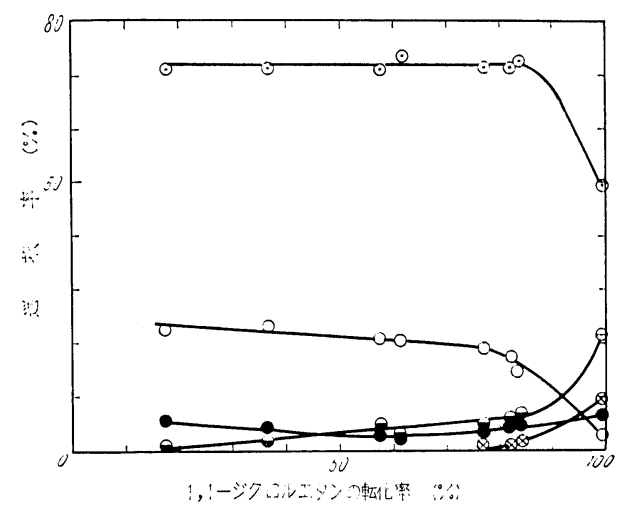

図 2 1,1-ジクロルエタンの転化婆と選択摔の闺係

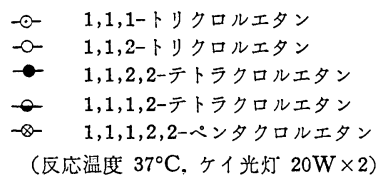

表 1 浴媒および添加羭の效果

\begin{tabular}{|c|c|c|c|c|c|c|c|}
\hline \multirow{2}{*}{ 溶媒および添加剤 } & \multirow{2}{*}{$\begin{array}{c}\text { 溶媒 濃 度 } \\
(\mathrm{mol} / \mathrm{l})\end{array}$} & \multirow{2}{*}{$\begin{array}{c}\text { 反応温度 } \\
\left({ }^{\circ} \mathrm{C}\right)\end{array}$} & \multirow{2}{*}{$\begin{array}{l}\text { 吹込塩素/ } \\
\mathrm{CH} \mathrm{Cl}_{3} \mathrm{CH} \mathrm{Cl}_{2} \\
(\mathrm{~mol} / \mathrm{mol})\end{array}$} & \multirow{2}{*}{\begin{tabular}{|l}
$\mathrm{CH}_{8} \mathrm{CCl}_{8}$ \\
選 択 率 \\
$(\%)$
\end{tabular}} & \multicolumn{2}{|c|}{ 化 率 (\%) } & \multirow{2}{*}{$\begin{array}{l}\text { 光源むよび反応 } \\
\text { 管との距離 }(\mathrm{cm})\end{array}$} \\
\hline & & & & & 素 & $\mathrm{CH}_{3} \mathrm{CHCl}_{2}$ & \\
\hline 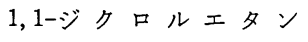 & - & 37 & 1.00 & 72.0 & 78.0 & 74.2 & ケイ光灯 $20 \mathrm{~W} \times 2$ \\
\hline ベ ン ゼ ン & 6.44 & 45 & 0.50 & 84.0 & 100.0 & 30.3 & " \\
\hline ジメチルフォルムアマイド & 3.82 & 37 & 1.00 & 68.4 & 15.2 & 14.0 & $"$ \\
\hline 二 硫 化 炭 素 & 8.03 & 37 & 1.00 & 85.3 & 31.9 & 27.8 & 水銀灯 \\
\hline$" \prime$ & 8.03 & 37 & 1.00 & 86.2 & 22.3 & 22.3 & " 17 \\
\hline & 8.03 & 37 & 1.00 & 87.1 & 24.2 & 25.9 & ケイ光灯 $20 \mathrm{~W} \times 1$ \\
\hline a & 8.03 & 37 & 1.00 & 87.3 & 46.7 & 29.4 & " $\quad 20 \mathrm{~W} \times 2$ \\
\hline $\mathrm{b}$ & 8.03 & 37 & 1.00 & 88.1 & 24.9 & 25.0 & $"$ \\
\hline =トロベンゼン & 4.83 & 37 & 0.99 & 18.0 & 4.1 & 1.7 & $"$ \\
\hline$"$ & 2.62 & 37 & 1.00 & 46.3 & 10.4 & 6.9 & $"$ \\
\hline 四 塩 化 炭 & 4.95 & 37 & 1.00 & 71.9 & 73.9 & 74.5 & 水銀灯 \\
\hline " & 4.39 & 37 & 1.00 & 70.4 & 88.1 & 89.2 & 19 \\
\hline 1,1,1-トリクロルエタン & 4.71 & 37 & 1.00 & 78.5 & 83.3 & 74.1 & $" \prime$ \\
\hline 酸䒺 & $\mathrm{d}$ & 37 & 1.00 & 67.8 & 44.5 & 49.5 & " 20 \\
\hline ヘキサクロルエタン & $24.0 \mathrm{e}$ & 37 & 0.40 & 74.5 & 98.1 & 35.5 & ケイ光灯 $20 \mathrm{~W} \times 2$ \\
\hline
\end{tabular}

a. 過酸化ベンゾイル $0.5 \%$ 添加，b. アゾビスイソブチロニトリル $0.5 \%$ 添加, c. 塩化第 2 鉄 $3.6 \%$ 添加, d. $\mathrm{O}_{2} ; 30 \mathrm{ml} / \mathrm{min}$, およざ $\mathrm{Cl}_{2} ; 30 \mathrm{~m} l l$ min., e. g/1,1-ジクロルエタン $100 \mathrm{~g}$. 
これによれば 1,1-ジクロルエタンの転化率が $80 \%$ を 越えるまでは 1,1,1-トリクロルエタンの選択率は約 70\% でほぼ一定である。したがって 1,1,1-トリクロル エタンの選択率を高めるためには，生成物がこれ以上塩 素置換されるのを防ぐと共に，1１，2-トリクロルエタン の生成を防ぐことが主な問題である。Russel12 4) らは親 電子的な塩素原子が電子密度の高、塩基性溶媒とコンプ レックスを作り，このものが炭化水素の炭素攻撃位置を 選択することを知った。

そこで塩基性が強く, 塩素原子とコンプレックスを作 る可能性のある各種溶媒および添加剤の効果を検討して 表 1 の結果を得た。

ベンゼンを用いると選択率が増加したが，それ自身塩 素化されやすいのが欠点である。ジメチルホルムアミド (DMF) は塩基性溶媒としてオレフィンへの塩素付加反 応に特異な効果を与えるが ${ }^{5}$ ) 本実験では 選択率の向上 はみられず，塩素とジクロルエタンの転化率が小さいこ とから, 塩素原子と DMF のコンプレックスは安定で反 応性に乏しいものと思われる。

四塩化炭素もやや効果があるが, 電子吸引性の置換基 をもち芳香核中の電子密度の小さいニトロベンゼンでは 著しく選択率が低下した。

ベンゼン等のそれ自身塩素化され易い溶媒は塩素の吹 き込み速度を下げて反応液中の塩素濃度を低下させるこ とによってこの欠点を回避することは可能であろうが， 二硫化炭素はこのよらな欠点が極めて小さく，しかも選 択率を向上させる作用が大きいので，実用上最も有利で あると思われた。

また，1,1,1ートリクロルエタンはかなり大きな効果を むつが，これもみずからさらに多塩素化され易いのが欠 点である。

表 1 に扔いて選択率の大きい場合には塩素とジクロル エタンの転化率が極めて小さいことが認められる。これ は反応速度が低下し, 塩素が反応系外に逸出したためで ある。

このことから連鎖反応を抑制するため酸素を加えたが 転化率の低下に比べて選択率への影響涊認られなかっ た。これは塩素原子の攻撃によって 1,1-ジクロルエタ ンから水素がひきぬかれて生じたラジカルが大量に存在 する酸素に捕捉された結果であると思われる ${ }^{8)}$ 。

逆に二硫化炭素を加えた反応系にラジカル開始剤を加 えて反応を促進しても選択率に変化がみられなかった。

また先に述べたように，1１１１-トリクロルエタンが選 択率を増加させるがそれ自身塩素化され易いためへキサ クロルエタンを添加したところ効果はみられなかった。
2. 二硫化炭素の効果 二硫化炭素-塩素コンプレ ックスの特殊性に注目して，この場合の反応条件と選択 率との関係を詳細に検討した。

i. 濃度の転化率への影響 溶媒に二硫化炭素を用、 た場合の生成物の組成と 1,1-ジクロルエタンの転化率 の関係を図 3 に示した。

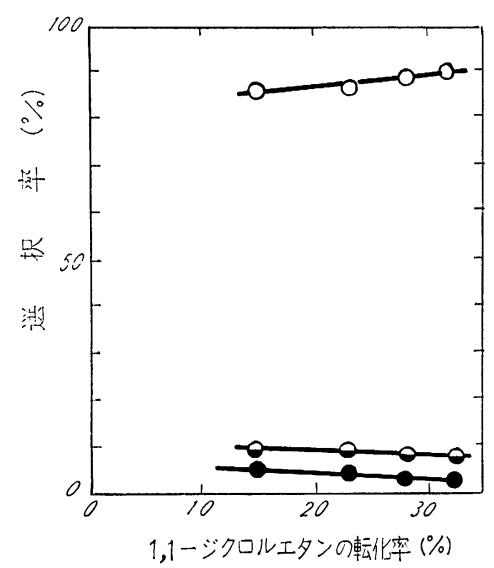

図 3 1,1-ジクロルエタンの転化率と選択率の關係

$$
\begin{aligned}
& \text { ○ 1,1,1-トリクロルエタン } \\
& \text { (1,1,2-トリクロルエタン } \\
& \text { - 1,1,2,2-テトラクロルエタン } \\
& \text { 二硫化炭素の濃度 } 8.03 \mathrm{~mol} / \mathrm{l} \text {, } \\
& \text { 反応温度 } 37^{\circ} \mathrm{C} \text {, ケ 光灯 } 20 \mathrm{~W} \times 2
\end{aligned}
$$

転化率の増加と共に 1,1,1-トリクロルエタンの選択 率が増加する傾向は, 他の濃度においても同様にみられ る。この理由は明らかではないが，反応が進行するにつ れ 1,1,1-トリクロルエタンが生成し，これが表 1 のよ うに選択率の向上をもたらしたものか，1１-ジクロルエ タンの減少と共に二硫化炭素の 1,1-ジクロルエタンに 対する相対濃度比が増加したためと考えられる。

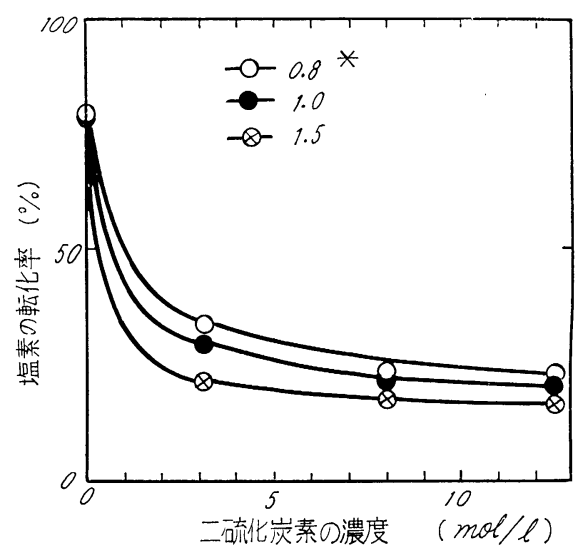

図 4 二硫化炭羕の濃度が塩素の転化率におよぼす影響 反応温度: $37^{\circ} \mathrm{C}, \mathrm{Cl}_{2}: 30 \mathrm{ml} / \mathrm{min}$. ケイ光灯 $20 \mathrm{~W} \times 2$. ${ }^{*} \mathrm{Cl}_{2} / \mathrm{CH}_{3} \mathrm{CHCl}_{2}(\mathrm{~mol} / \mathrm{mol})$ 


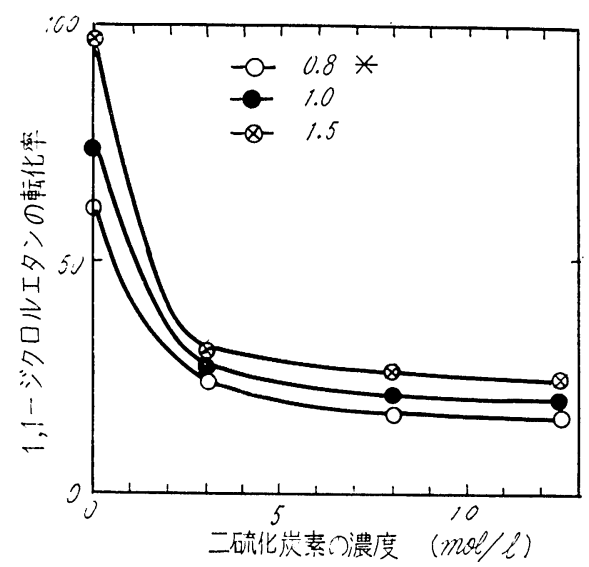

図 5 二硫化炭素の濃度が 1,1-ジクロルエタンの 転化率におよぼす影響

反応温度 $37^{\circ} \mathrm{C}, \mathrm{Cl}_{2} 30 \mathrm{ml} / \mathrm{min}$. ケ化光灯 $20 \mathrm{~W} \times 2$ ${ }^{*} \mathrm{Cl}_{2} / \mathrm{CH}_{3} \mathrm{CHCl}_{2}(\mathrm{~mol} / \mathrm{mol})$

図 4 および 5 では液量に対して一定の速度で塩素を 吹きこむときに, 二硫化炭素の濃度が増加すると, 濃度 の低、領城では転化率が急激に減少するが，それ以上で は徐々に減少することを示している。

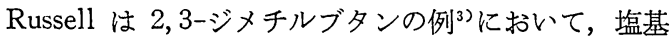
性溶媒が存在する場合の塩素置換反応機構について塩素 原子に対する溶媒の果す役割を論じているが，これらの 実験結果もこの考え方をとり入れるならば良く理解でき る。すなわち

$$
\begin{aligned}
& \mathrm{Cl} \cdot+\mathrm{CH}_{3} \mathrm{CHCl}_{2} \longrightarrow \cdot \mathrm{CH}_{2} \mathrm{CHCl}_{2}+\mathrm{HCl} \cdots \cdots[1] \\
& \mathrm{Cl} \cdot+\mathrm{CH}_{3} \mathrm{CHCl}_{2} \longrightarrow \mathrm{CH}_{3} \dot{\mathrm{C} C l}{ }_{2}+\mathrm{HCl} \\
& \mathrm{Cl} \cdot+x \mathrm{CS}_{2} \leftrightarrows x \mathrm{CS}_{2} \rightarrow \mathrm{Cl} \cdot(1) \\
& \text { (1) }+\mathrm{CH}_{3} \mathrm{CHCl}_{2} \\
& \longrightarrow \cdot \mathrm{CH}_{2} \mathrm{CHCl}_{2}+\mathrm{HCl}+x \mathrm{CS}_{2} \\
& \text { (1) }+\mathrm{CH}_{3} \mathrm{CHCl}_{2} \\
& \longrightarrow \mathrm{CH}_{3} \dot{\mathrm{C}} \mathrm{Cl}_{2}+\mathrm{HCl}+x \mathrm{CS}_{2} \\
& \mathrm{CH}_{3} \dot{\mathrm{CCl}}_{2}+\mathrm{Cl}_{2} \longrightarrow \mathrm{CH}_{3} \mathrm{CCl}_{3}+\mathrm{Cl} \text {. }
\end{aligned}
$$

ここで $x$ は二硫化炭素の結合モル数を示す。

〔3〕の平衡式によって塩素原子が錯体化され，形成され た〔4]と〔5]のコンプレックスと 1,1-ジクロルエタン との反応速度に比べて，〔1〕および〔2〕は通常の塩素置 換反応であってその速度が早い。[5]は〔4】より速やか に進むため〔7]によって 1,1,1-トリクロルエタンが 1, 1,2-トリクロルエタンより多く生成する。

さらに図 4 および 5 における転化率の急激な減少は二 硫化炭素と 1,1-ジクロルエタンのモル数が等しい付近 (8.35 mol ll) でほぼ一定值をとっていることから [3]，
〔4〕および〔5〕の反応が進んでいる状態を示すものと思 われる。

ii. 濃度, 反応温度およひ選 択率の関係 図 6 は二 硫化炭素の濃度の反応生成物組成への影響を示す。

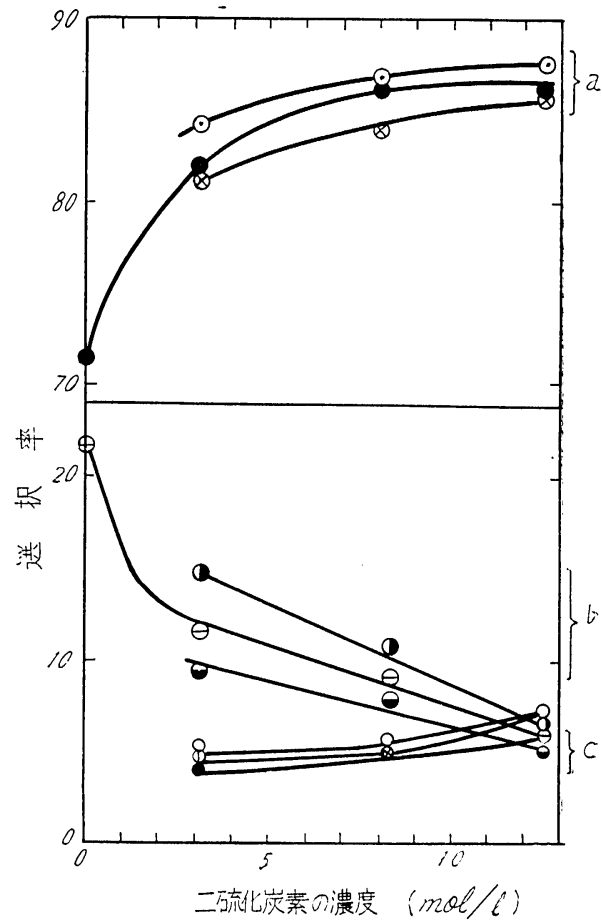

图 $6 \mathrm{CS}_{2}$ の濃度と選択率の関係

a : 1,1,1-トリクロルエタン, b : 1,1,2-トリクロルエタン, c : 1,1,2,2-テトラクロルエタン

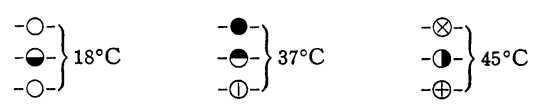

1,1-シクロルエタンの転化率：15\%，ケイ光灯 $20 \mathrm{~W} \times 2$

二硫化炭素の濃度の増加と共に 1,1,1-トリクロルエ タンの選択率が増加する一方，1，1，2-トリクロルエタン の選択率の減少が各温度においてみられるが, 濃度が $8 \mathrm{~mol} / l$ 以上の二硫化炭 素は効果が少ないことが認めら れる。

また逐次反応としては二硫化炭素が存在すると 1,1 , 2,2-テトラクロルエタンのみが生成した。ここで右田 ら 9) が溶液中のクロルエチル遊離基の反応について提示 している反応過程を 1, 1, 2, 2-テトラクロルエタンの生 成経路に用いた場合，この結果が説明できる。

すなわちコンプレックスによる水素引きぬきに対する 1位の水素原子の反応性から 1,1,2-トリクロルエタン は次の遊離基を生ずる。

$\left(\mathrm{CS}_{2}\right)-\mathrm{Cl} \cdot+\mathrm{CH}_{2} \mathrm{ClCHCl}_{2} \longrightarrow \mathrm{HCl}+\cdot \mathrm{CHClCHCl}_{2}$ 
このクロルエチル遊離基は $\beta$-分裂および塩素に関する 不均化を行う。

- $\mathrm{CHClCHCl}_{2} \longrightarrow \mathrm{Cl} \cdot+\mathrm{CHCl}=\mathrm{CHCl}$

$2 \cdot \mathrm{CHClCHCl}_{2} \longrightarrow \mathrm{CHCl}_{2} \mathrm{CHCl}_{2}+\mathrm{CHCl}=\mathrm{CHCl}$

この放出された塩素原子および系内に過剰に溶解して いる塩素原子が生成した 1,2-ジクロルエチレンに付加 してオレフィンは消滅したと考えられる。また塩化水素 の発生が明白に認められることから彼らの提 案する $\beta-$

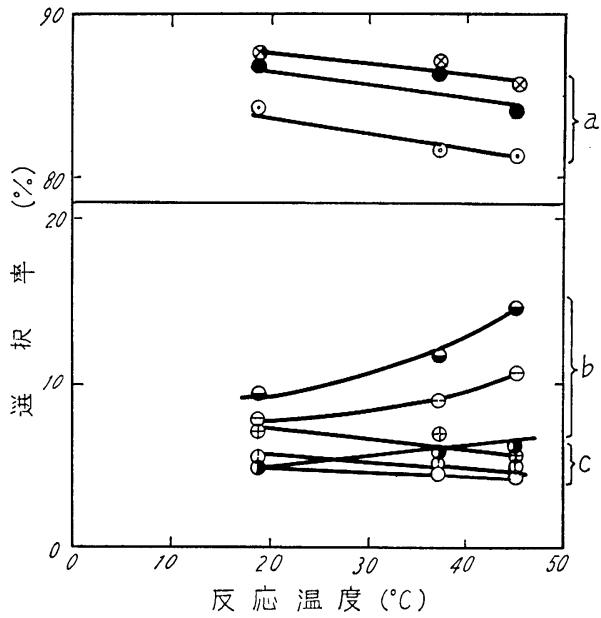

図 7 反応温度と選択率の関係

a : 1,1,1-トリクロルエタン, b : 1,1,2-トリクロルエタン c : 1,1,2,2-テトラクロルエタン

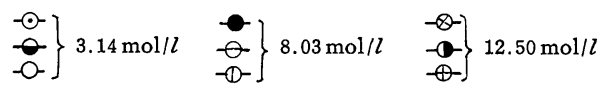

1,1-ジクロルエタンの転化率: $15 \%$,ケイ光灯 $20 \mathrm{~W} \times 2$
分裂がおこっている証拠を示す。

図 7 には反応温度が反応生成物へおよぼす影響を示 した。

二硫化炭素が存在すると反応温度が低い程 $1,1,1-$ 卜 リクロルエタンが増加し，1,1,2-トリクロルエタンの選 択率が低下する傾向が認められる。

これらの結果から，1,1-ジクロルエタンを二硫化炭素 の存在下に光塩素化すると選択率に効果を与える最少濃 度 $8 \mathrm{~mol} / l$ において, 反応温度が $18 \sim 45^{\circ} \mathrm{C}$ の範囲で は，85〜90\% の選択率で 1,1,1-トリクロルエタンが得 られた。

また反応温度を 低くさせると $1,1,1$-トリクロルエタ ンの選択率はさらに向上するものと考えられる。

\section{文献}

1) A.J. Haefner, F. Conrad, USP 3, 019, 175 (1962)

2) C. Walling, M.F. Mayahi, J. Am. Chem. Soc. 811485 (1959)

3) G.A. Russell, J. Am. Chem. Soc. 804987 (1958)

4) G.A. Russell, J. Am. Chem. Soc. 792977 (1957)

5) H.F. Wilson, USP 2, 823, 232 (1958)

6) C.D. Burton, USP 2, 647, 923 (1953)

7) M. Minsinger, H. Friederich, USP 2, 813, 893 (1957)

8) C. Walling, Free Radicals in Solution p. 352 (1957), J. Wiley and Sons, Inc., New York

9) 右田, 小杉, 河野, 永井, 有合化 24223 (1966) 